УДК 378.1

DOI: $10.15330 /$ esu. 1.7-12

\section{Ірина Вербій,}

викладач, Херсонська державна морська академія, аспірант КВНЗ "Херсонська академія неперервної освіти" (м. Херсон, Україна)

Iryna Verbii,

Teacher, Kherson State Maritime Academy, postgraduate CHEE "Kherson academy of continuous education" (Kherson, Ukraine)

ireneverbiy88@gmail.com

\title{
СУСПІЛЬНО-ГУМАНІТАРНІ ДИСЦИПЛІНИ У МОРСЬКИХ НАВЧАЛЬНИХ ЗАКЛАДАХ ЯК ЗАСІБ РЕАЛІЗАЦІЇ СОЦІОКУЛЬТУРНОЇ СКЛАДОВОЇ ОСВІТИ (1991-2019 PP.)
}

\section{SOCIAL AND HUMANITARIAN DISCIPLINES IN MARITIME EDUCATION AS A MEANS OF REALIZING SOCIO-CULTURAL COMPONENT OF EDUCATION} (1991-2019)

У статті проаналізовано суспільно-гуманітарні дисципліни у морських навчальних закладах як засіб реалізачї сочіокультурної складової освіти у 1991-2019 рр. Розглянуто нормативно-правову базу відповідно до якої регулювався перелік дисциплін та їх належність до нормативних чи вибіркових. 3 'ясовано, що у незалежній Украйні важливим завданиям була гуманітаризачія освіти тому кількість суспільно-гуманітариих дисциплін почала збільиуватись. Так, у відповідності до Інструктивного листа міністерства освіти України 스1/9-64 від 19.05.1993 р. “Про викладання сочіально-гуманітарних дисииплін” у навчальні плани додавався ряд сочіально-гуманітарних дисииплін. Охарактеризовано дані дисиипліни на основі збережених у архіві навчальних програм Херсонської державної морської академії та Морського коледжу.

Ключові слова: суспільно-гуманітарні дисчипліни, морський навчальний заклад, сочіокультурна складова освіти, нормативиі, вибіркові дисчипліни.

The article analyzes social and humanitarian disciplines in maritime educational institutions as a means of realizing the socio-cultural component of education in 1991-2019. It was found that in an independent Ukraine an important task was the humanization of education, so the number of social and humanitarian disciplines began to increase. Thus, in accordance with the Instruction letter of the Ministry of Education of Ukraine №1/9-64 of 19.05.1993 "On the teaching of social and humanitarian disciplines" a number of social and humanitarian disciplines were added to the curricula. The following disciplines have been characterized on the basis of the curricula stored in the archives of Kherson State Maritime Academy and Maritime College. Within the chosen period of time, curricula and the names of disciplines have changed but among those realizing socio-cultural component belonging to the cycle of humanities and social-economic sciences are: "History of Ukraine", "Business Ukrainian language", "Ukrainian and foreign culture", "Philosophy", "Fundamentals of psychology and pedagogy", "Religious Studies", "Fundamentals of Economic Theory", "Political Science", "Fundamentals of Law", "Sociology", "Fundamentals of Constitutional Law of Ukraine", "English". The analysis of the social and humanitarian disciplines of maritime educational institutions gives grounds to claim that these disciplines fully contribute to the implementation of the socio-cultural component of education in 1991-2019 and are, for the most part, closely linked, one discipline being the basis for studying 
others and vice versa. Their list, content, as well as their affiliation to the normative or selective disciplines were established in accordance with the current laws, regulations, orders, normative documents.

Key words: social and humanitarian disciplines, maritime educational institution, sociocultural component of education, normative, selective disciplines.

Суспільно-гуманітарні дисципліни разом 3 дисциплінами професійного спрямування формують особистість майбутнього фахівця. Соціокультурна складова освіти, що реалізується через них, спрямована на успішне оволодіння спеціалістом основ міжкультурного спілкування, адекватним поводженням у ситуаціях, пов'язаних 3 культурою, історією, мовою, традиціями, звичками та нормами поведінки різних народів. У радянському союзі суспільні науки були спрямовані на вивчення марксистсько-ленінської філософії та не терпіли вільнодумства, тому після проголошення незалежності України багато суспільствознавчих дисциплін було вилучено або скорочено час на їх вивчення. Проте, згодом було вжито заходів щодо відновлення вивчення суспільно-гуманітарних дисциплін відповідно до вимог незалежної країни.

Дослідженням соціокультурної компетентності займались вітчизняні вчені Л. Ліпшиць, А. Мурзіна, О. Фролова, Я. Никорак, І. Червінська. М. Бабишена, Г. Балл, О. Бобіна, І. Зязюн, І. Матійків, Л. Тархан та ін. цікавились проблемами гуманітаризації освіти.

Метою нашої статті $€$ аналіз суспільно-гуманітарних дисциплін морських навчальних закладів, що слугують засобом реалізації соціокультурної складової освіти у 1991-2019 рр.

Зі здобуттям Україною незалежності розпочався процес реформування всіх сфер суспільства, не стала виключенням й освіта. 04.06.1991 р. в дію було введено оновлений Закон "Про освіту", положення якого базувались на засадах попереднього Закону УРСР від 1974 р. "Про народну освіту". Подальше реформування освітньої галузі відбувалось згідно із Законом України від 25.04.1996 p. "Про освіту", Законом України від 17.01.2002 р. та від 01.07.2014 р. "Про вищу освіту", Законом України від 05.09.2017 р. "Про освіту".

Згідно 3 концепцією та Постановою спільної колегії міністерств вищої освіти, народної освіти, культури, охорони здоров'я, торгівлі, Комітету у справах молоді, фізкультури та спорту за № 6-1/210 від 15.05.1991 “Про викладання гуманітарних та соціально-політичних дисциплін у вищих, середніх спеціальних навчальних закладах республіки", відсоток гуманітарних і соціально-політичних дисциплін, а також спецкурсів мав становити 20-25\% від загального обсягу навчальних годин для інженерних спеціальностей та 30-35\% для технічних, гуманітарних тощо [6, с. 7-8]. 31993 р. розпочинається гуманізація освіти, у навчальних планах збільшується кількість дисциплін гуманітарного циклу. Даний процес передбачався Інструктивним листом міністерства освіти України №1/9-64 від 19.05.1993 р. “Про викладання соціально-гуманітарних дисциплін”. Відповідно до нього було скориговано навчальні плани та розширено вивчення дисциплін соціальногуманітарного циклу, також з'явились нові дисципліни. Згідно з навчальним планом Херсонського морського училища 1993 р., до предметів, які засвідчують наявність соціокультурної складової у морських навчальних закладах, відносяться: "Всесвітня історія", "Українська мова", "Українська література", “Ділова українська мова", “Світова література", “Історія України”, “Філософія з релігієзнавством”, “Англійська 
мова", “Політологія", “Соціологія”, “Українська та зарубіжна культура". Положення щодо навчальних планів, програм та дисциплін у вищих навчальних закладах викладено у наказі Міністерства освіти України № 161 від 02.06.1993р. Так, “зміст освіти визначається освітньо-професійною програмою підготовки, структурнологічною схемою підготовки, навчальними програмами дисциплін, іншими нормативними актами органів державного управління освітою та вищого навчального закладу, відображається у відповідних підручниках, навчальних посібниках, методичних матеріалах, дидактичних засобах, а також при проведенні навчальних занять та інших видів навчальної діяльності" [4]. Крім того, наказом передбачено, що нормативні дисципліни встановлюються державним стандартом, а вибіркові - вищим навчальним закладом. Останніми могли бути й гуманітарні, якщо вони слугували для “задоволення освітніх i кваліфікаційних потреб особи, ефективного використання можливостей i традицій конкретного навчального закладу, регіональних потреб тощо [4]. Згідно з листом №1/9-64 від 19.05.1993 р. у навчальних закладах, які не готують студентів з педагогічних чи мистецтвознавчих спеціальностей, тобто морських навчальних закладах також, за рішенням рад обиралось не менше чотирьох курсів, з яких два - обов'язкові, 3 них складається іспит, а решта - спецкурси за вибором [6, с. 8-9].

Лист Міністерства освіти України “Про розробку освітньо-професійних програм вищої освіти за відповідним професійним спрямуванням" № 1/9-18 від 18.02.1994 р. передбачав у освітньо-професійних програмах цикл гуманітарних та соціально-економічних дисциплін як складову нормативних, тобто обов'язкових дисциплін. За чотирирічний термін навчання обсяг годин даного циклу повинен був становити до 26\% від нормативних навчальних дисциплін [6, с. 9].

Студіювання навчальних планів Херсонського морського коледжу за 19992000 н.р. дає підстави констатувати велику кількість нормативних дисциплін, що належать до циклу гуманітарних та соціально-економічних, а саме: "Історія України", “Ділова українська мова", "Українська та зарубіжна культура", "Філософія", "Основи психології та педагогіки", "Релігієзнавство", "Основи економічної теорії, "Політологія", “Основи права”, “Соціологія", “Основи конституційного права України”, “Англійська мова". Але у навчальному плані названого морського навчального закладу їх об'єднано під назвою “Соціальногуманітарний та природничий цикл” разом 3 “Хімією”, “Біологією” тощо. [1, с. 30]. Для отримання освітньо-кваліфікаційного рівня “молодший спеціаліст" разом 3 іспитами 3 професійних дисциплін як "Судноводіння", та "Управління судном", необхідно було скласти “Ділову українську мову”.

Як зазначає П. Шляхтун [6], цикл гуманітарних та соціально-економічних дисциплін було скориговано ще декілька разів, спочатку листом Міністерства освіти i науки України "Про організацію навчального процесу у вищих навчальних закладах у 2002/2003 навчальному році" № 1/9-304 від 17.06.2002, де визначався перелік та обсяг годин на вивчення зазначених дисциплін, а потім у липні 2009 р. наказом Міністерства освіти i науки України "Про організацію вивчення гуманітарних дисциплін за вільним вибором студента" № 642 від 09.07.2009 р. Згідно 3 наказом встановлювався перелік нормативних дисциплін гуманітарної та соціально-економічної підготовки для бакалаврів (табл. 1). 


\begin{tabular}{|l|c|}
\hline \multicolumn{1}{|c|}{ Нормативні дисципліни } & Обсяг кредитів ECTS \\
\hline $\begin{array}{l}\text { Українська мова } \\
\text { (за професійним спрямуванням) }\end{array}$ & 3 \\
\hline Історія України & 3 \\
\hline Історія української культури & 2 \\
\hline Іноземна мова & 5 \\
\hline Філософія & 3 \\
\hline
\end{tabular}

Відповідно, близько 20 дисциплін було віднесено до вибіркових, а у 2010 p. наказ Міністерства освіти і науки України "Про внесення змін до наказу МОН від 09.07.2009 p. №642” № 831 від 25.08.2010 звузив їх перелік до дев’яти: "Політологія", “Соціологія", “Психологія", “логіка", “Етика і естетика", "Релігієзнавство", “Основи конституційного права", "Економіка", “Історія науки i техніки" [3]. Згідно з наказом Міністерства освіти і науки України "Про внесення змін до наказу МОН від 09.07.2009 р. №642” № 939 від 05.08.2011 до переліку нормативних дисциплін було додано “Політологію”. У зв'язку з прийняттям Закону України від 1 липня 2014 р. № 1556-VII “Про вищу освіту”, наказ втратив чинність.

Ще до проголошення незалежності в УРСР розпочалося відродження, популяризація української мови. Постанова ВР № 8313-11 від 28.10.1989 р. затвердила Закон УРСР “Про мови в Українській РСР”. На підставі цього закону було складено та затверджено “Державну програму розвитку української мови та інших національних мов в Українській РСР на період до 2000 року”. Закон визначав українську мову як мову навчання та виховання, у випадках навчання іноземних або громадян інших союзних республік було передбачено створення груп з відповідною національною мовою, але навіть у неукраїномовних навчальних закладах забезпечувалось вивчення української мови. Мовна реформа відбувалась дещо мляво, зокрема у “Інформаційному збірнику Міністерства освіти України” за 1992 р. сказано, що темпи іiі запровадження у Херсонській області “ще не відповідають сучасним потребам i завданням розбудови національної освіти, утвердженню державного статусу української мови" [5, с. 3]. Тому колегією Міністерства освіти України було поставлено завдання забезпечити використання державної мови протягом усього дня, включаючи позакласні заходи; викладати всі навчальні предмети українською та матеріально заохотити педагогічних працівників, які перейшли на викладання державною мовою за рахунок місцевих ресурсів; вищим i професійно-технічним навчальним закладам надавалась допомога щодо видання українськомовної навчальної літератури [там само, с. 3-6]. Отже, за рахунок прищеплення любові до державної мови, заохочення до іiі використання у всіх сферах життя, а не лише у навчанні, мала формуватися національна самосвідомість, грамотність, повага до культури свого народу.

Розглянемо навчальні програми 3 дисциплін, що реалізують соціокультурну складову, на прикладі Херсонського морського коледжу та Херсонського державного морського інституту (з 2011 р. - академії). У державному архіві Херсонської області збережено програми 2000-их років, до них і звернемось. Як зазначено у програмі з "Української мови", іiі вивчення "полягає у формуванні національно свідомої, духовно багатої мовної особистості, яка володіє вміннями та навичками вільно, комунікативно виправдано користуватися засобами рідної мови". Також 
даний предмет “має за мету прищепити переконання у потребі спілкування державною мовою, любов до рідної мови, почуття національної гордості, потребу систематичного мовного і мовленнєвого самовдосконалення і збагачення" [2, с. 38]. У методичних вказівках шодо вивчення "Української мови" наголошується, що мова як наука має культурні, соціальні, політичні аспекти. Існує поняття культури мовлення, що передбачає здатність курсантів мати сучасні світоглядні орієнтири, усвідомлювати єдність людини 3 родом, народом, людством, помічати красу у природі, людині, мистецтві, побуті тощо, мати здатність до моральної самооцінки, слідувати загальнолюдським моральним нормам та знати основні ознаки історичного розвитку України як політичного, господарського, так і культурного [там само]. Культурологічна змістова лінія відображає саме соціокультурну складову даного предмета. Національній самосвідомості, моральному i художньому вихованню сприяє й "Українська література". Згідно з програмою, курсанти вивчають українську народну творчість, думи, балади, ліричні пісні, народний епос, що виховує високі морально-етичні якості та естетичне відношення до дійсності. Основні етапи розвитку літератури допомагають засвоїти елементи культурної спадщини, історію, погляди народу та окремих письменників чи поетів на істину і красу [там само, с. 55]. Засобом реалізації соціокультурної складової освіти $€$ й предмет “Зарубіжна література", адже шляхом залучення курсантів до скарбниці світової літератури формується особистість з духовно-ціннісними орієнтаціями, культурно-пізнавальними інтересами та естетичним смаком. Одним із завдань курсу "Зарубіжної літератури" є виховання поваги до інших національних традицій, розуміння власної культури, національної своєрідності та внеску української культури у розвиток світової. Курсанти вивчають поезію та прозу найвидатніших поетів та письменників та за рахунок міжпредметних зв'язків покращують знання 3 історії та світової культури. Історія України, як йдеться у програмі на 2003-2004 н.р., “займає важливе місце серед предметів соціально-гуманітарного циклу, які покликані розширювати кругозір курсантів та духовно розвивати їх особистість... курс сприяє формуванню національної свідомості та поваги до своєї Батьківщини" [2, с. 3]. У програмі зазначено, що "Історія України є базою для подальшого вивчення "Культурологіі", "Соціологіï" та "Політології". Дисципліна сприяє формуванню переконань відповідно до ідеалів гуманізму та патріотизму. Предмет “Економічна і соціальна географія світу" через вивчення шляхів охорони навколишнього середовища та положень міжнародних конвенцій, таких як МАРПОЛ 73/78 та ПДНВ 78/95, виховує у курсантів "переконання у необхідності бережливого відношення до природи, необхідність міжнародного співробітництва в рішенні проблеми охорони навколишнього середовища; виховання особистого ставлення до конкретних фактів нераціонального використання природних багатств" [там само, с. 21], що також робить іiі дисципліною, котра формує соціокультурну компетентність. Далі розглянемо "Англійську мову (загального спрямування)" та “Англійську мову (професійного спрямування)". Так у навчальному плані на 2005-2006 н.р. наголошується, що мовленнєві вміння, набуті курсантами під час вивчення англійської мови сприяють їх комунікативності, окрім явищ, притаманних рідній мові, вони вивчають історію, літературу, мистецтво загалом та пізнають культуру носіїв англійської. На заняттях 3 “Англійської мови (загального спрямування)" вивчаються теми як про Україну, наприклад, “Україна", “Київ”, “Українська діаспора за кордоном" так і про англомовні країни та міста ("Великобританія", "США", “Лондон", "Вашингтон"), їх традиції, що збагачує соціокультурні знання курсантів [там само, с. 98-101]. Окрім 
наведених дисциплін курсанти Херсонського морського коледжу вивчали “Мистецтво танцю”, “Основи філософських знань (філософія, релігієзнавство)" або "Філософію" та "Релігієзнавство" як окремі предмети, "Філософські проблеми наукового пізнання", “Культурологію”, “Соціологію". Але навчальні плани могли дещо коригуватись, наприклад програма 3 "Мистецтва танцю" є лише на 2003-2004 н.p., невідомо як довго викладалась ця дисципліна. Тому за відсутності багатьох навчальних планів та програм дисциплін досліджуваного періоду важко стверджувати як змінювався їхній перелік та зміст. У 2018-2019 н.р. у Херсонській державній морській академії викладались такі гуманітарні дисципліни, що реалізують соціокультурний компонент освіти: “Історія та культура України”, “Філософія", "Українська мова (за професійним спрямуванням)", "Професійна етика науковця", "Науковий стиль української мови", "Історія та філософія науки", “Філософські проблеми наукового пізнання”, “Англійська мова (за проф. спрямуванням)” тощо.

Таким чином, аналіз суспільно-гуманітарних дисциплін морських навчальних закладів дає підстави стверджувати, що дані дисципліни цілком сприяють реалізації соціокультурної складової освіти у 1991-2019 pp. та здебільшого є тісно пов'язаними між собою, одна дисципліна може слугувати базою для вивчення інших i навпаки. Їх перелік, зміст, а також належність до нормативних чи вибіркових дисциплін встановлювались у відповідності до чинних законів, постанов, наказів, нормативних документів.

Перспективу подальших досліджень вбачаємо у аналізі програм дисциплін соціокультурного спрямування у другій половині ХХ ст.

\section{Література}

1. Навчальні плани на 1999-2000 навч.рік. Державний архів Херсонської області. Ф Р-. Оп. 4. Спр. 495.47 арк.

2. Навчальні програми із загальноосвітніх дисциплін 2000-2007 p.p. Державний архів Херсонської області. Ф. Р-. Оп. 1. Спр. 18. 206 арк.

3. Про внесення змін до наказу МОН від 09.07.2009 р. №642 № 831 від 25.08.2010: наказ МОН від 25.08.2010 № 831 URL: https://zakon.rada.gov.ua/rada/show/v0831290-10

4. Про затвердження Положення про організацію навчального процесу у виших навчальних закладах: наказ Міністерства освіти України від 02.06 .1993 p. № 161 . URL: http://zakon2.rada.gov.ua/laws/show/z0173-93/ed19930602 (дата звернення 26.08.2019).

5. Про стан запровадження Закону України про мови у навчальних закладах Херсонської об̆ласті. Інформаційний збірник Міністерства освіти України, № 4, 1993. С. 3-6.

6. Шляхтун П. П. Методика викладання соціально-гуманітарних дисциплін: навчальний посібник. Київ: Академія, 2011. 222 с.

\section{References}

1. Navchalni plany na 1999-2000 navch.rik. Derzhavnyi arkhiv Khersonskoi oblasti. F R-. Op. 4. Spr. 495. 47 ark.

2. Navchalni prohramy iz zahalnoosvitnikh dystsyplin 2000-2007 r.r. Derzhavnyi arkhiv Khersonskoi oblasti. F. R-. Op. 1. Spr. 18. 206 ark.

3. Pro vnesennia zmin do nakazu MON vid 09.07.2009 r. №642 № 831 vid 25.08.2010: nakaz MON vid 25.08.2010 № 831 URL: https://zakon.rada.gov.ua/rada/show/v0831290-10

4. Pro zatverdzhennia Polozhennia pro orhanizatsiiu navchalnoho protsesu u vyshchykh navchalnykh zakladakh: nakaz Ministerstva osvity Ukrainy vid 02.06 .1993 r. № 161. URL: http://zakon2.rada.gov.ua/laws/show/z0173-93/ed19930602 (data zvernennia 26.08.2019).

5. Pro stan zaprovadzhennia Zakonu Ukrainy pro movy u navchalnykh zakladakh Khersonskoi oblasti. Informatsiinyi zbirnyk Ministerstva osvity Ukrainy, № 4, 1993. S. 3-6.

6. Shliakhtun P. P. Metodyka vykladannia sotsialno-humanitarnykh dystsyplin: navchalnyi posibnyk. Kyiv: Akademiia, 2011.222 s. 